\title{
Effect of the corn-cowpea association on the
} organic carbon dynamics of the soils of two plots in real culture in northern Côte d'Ivoire

\author{
N'GUESSAN Kouamé Antoine*, DIARRASSOUBA Nafan, OUATTARA \\ N'Klo and KONAN N'dré Pélagie
}

Peleforo Gon Coulibaly University, Faculty of Biological Sciences, Geosciences Department, BP 1328 Korhogo, Côte d'Ivoire. Corresponding author

N'GUESSAN Kouamé Antoine*. Teacher-researcher, Peleforo Gon Coulibaly University, Faculty of Biological Sciences, Geosciences Department. Cel : (225) 07426965 / (225) 52148204 E.mail : nguessanantoine1979@gmail.com

\begin{abstract}
Declining soil fertility is a major factor in low agricultural production and increases food insecurity in northern Côte d'Ivoire. The objective of this study is to understand the real influence of cowpea in the corncowpea association modalities on the evolution of organic carbon $(C)$ and nitrogen $(N)$ contents in the soil on the scale of plot compared to control soils without cowpea and fallow more than 30 years. In this perspective, two farmer field plots were conducted in a participatory manner with two groups of corn producers in the localities of Kolokaha and Sohouo (Department of Korhogo) in order to assess the effect of the semi density of cowpea (Vigna unguiculata L.) on the initial physical and chemical characteristics of the soil. In the open field, four (4) treatments corresponding to corn in pure culture (TO); corn + cowpea interposed online (T1-SNL); corn + cowpea in double intersected line (T2-SNDLI) and corn + cowpea staggered (T3-SNQ) were tested in three (3) completely randomized blocks with three repeats. Thirty-two (32) composite soil samples from natural fallows and TO, T1-SNL and T2-SNDLI treatments were taken and analyzed in the laboratory. The results show a clear improvement in the organic carbon and nitrogen levels, and above all an increase in the soil pH in the plots in associated crops. The combination of corn and cowpeas is an alternative to good soil fertility management and could be recommended in rural areas.
\end{abstract}

Keywords—Soil fertility, association, semi density, yield, Côte d'Ivoire.

\section{INTRODUCTION}

Depletion and degradation of the soil, as well as climatic variability, are responsible for the decline in agricultural yields and worsen the poverty of the populations in the north of Côte d'Ivoire. With the high land and population pressure observed in this area, farmers are forced to practice continuous cultivation and make the most of the available land (N'guessan et al., (2019a); N'goran et al., 2018), as is the case in the cotton zone of Burkina Faso reported by Coulibaly et al., (2012), Barro et al., (2016), Ouattara et al., (2016) and Coulibaly et al., (2017). Under these conditions, fertile land has become increasingly scarce in the cotton basin and farmers are unable to allow their soils to rest sufficiently. This has resulted in the depletion of agricultural soils in organic matter and their enrichment in sand (n'goran et al., 2018; n'guessan et al., 2019a) under the constraint of changes in use and agricultural intensification. However, soils, as a direct feeding mother of plants and indirect animals, constitute for farmers the major capital necessary to ensure the production necessary for their well-being and, for many, the main source of their diet. Today, farmers are worried about the depletion of their soils, say that the land no longer produces as before (n'guessan et al., 2019b). While it is recognized that soil organic matter (MOS) conditions many soil properties and its management is an essential component of the sustainability of agrosystems, it is thought that the introduction of a more productive and sustainable farming system in the peasant environment, based on maintaining ecosystem functionality, appears to be a solution to help restore soil fertility and productivity in northern Côte d'Ivoire. Because in the traditional cotton and maize-based farming systems that predominate in the dense area of Korhogo department, the supply of mineral fertilizers alone does not maintain soil fertility. In this area, legumes occupy only a marginal part of the cultivation systems, although they can play a very important role, whether they are grown in rotation or in 
combination. Several studies on legumes indicate that they can improve soil fertility by symbiotic nitrogen fixation in the air (Gbakatchetche et al., 2010, Barro et al., 2016; Ouattara et al., 2016; Coulibaly et al., 2017 and Kouassi et al., 2017), to produce quality fodder for animals (Zoundi et al., 2006; Bambara et al., 2008 and Ouattara et al., 2016) and provide income for farms. However, with the high land and demographic pressure observed in recent years in the northern part of Côte d'Ivoire, the use of soil restoration technique with tree legumes becomes problematic. The use of herbaceous legumes thus becomes an alternative to improve soil fertility. Among these, cowpea appears to be the best choice because it is the main source of protein and food for rural and urban populations in the area (N'guessan et al, 2019a) as well as for livestock. To do this, the research question is the maize-legume combination method that can reduce competition between crops and promote improved yields. This study, funded by KOREA-Africa Food - Agriculture Cooperation Initiative (KAFACI) as part of the KAFACI-Young Scientist Pilot Research Project (period 2017-2019) aims to develop with producers, organically efficient and technically acceptable associated maize/cowpea crop systems by conducting experiments in real-world crop conditions. This study was undertaken to assess at the plot level the impact of the corn-cowpea association on the organic carbon dynamics of agrosystem soils.

\section{MATERIALS AND METHODS}

2.1. Study site
The study was conducted in the villages of Kolokaha and Sohouo respectively located in the Sub-Prefectures of Sinématiali and Sohouo in Korhogo Department (Figure 1). These two villages are mainly populated by the Senoofo a natives whose main activity is agriculture and livestock. The general model of the region is a tabular set of iron breance with gentle fractures caused by garlands of hills and mounds with rounded reliefs placed on mediumheight plateaus (Avenard et al., 1971). According to Beaudou and Sayol (1980), the geological substratum is made up of Calco-alkaline granites from the Precambrian. The soil cover of this region is characterized by the very large predominance of ferrallitic soils (Avenard et al., 1971). In terms of climate, the savannah district is bathed in a tropical Sudanese climate with two seasons, a dry season from November to April and a rainy season from May to October.

\subsection{Sampling methodology}

In each of the communities, the work was carried out after the maize harvest in December 2018, six (06) months after semi. Initially, each of the two demonstration plots had been gridded into 3 blocks and each block consisted of 3 sub-blocks subdivided into four $30 \mathrm{~m}^{2}$ elementary plots measuring $6 \mathrm{~m}$ long and $5 \mathrm{~m}$ wide. On each elementary plot, there were 13 lines and on each line, 15 poquets. Each $30 \mathrm{~m}^{2}$ elemental plot consisted of 195 corn plants per unit area on all three blocks. In the association system, maize and cowpea were placed in the elementary plots of each block and in blocks according to the schematic combination mode in Figure 2:

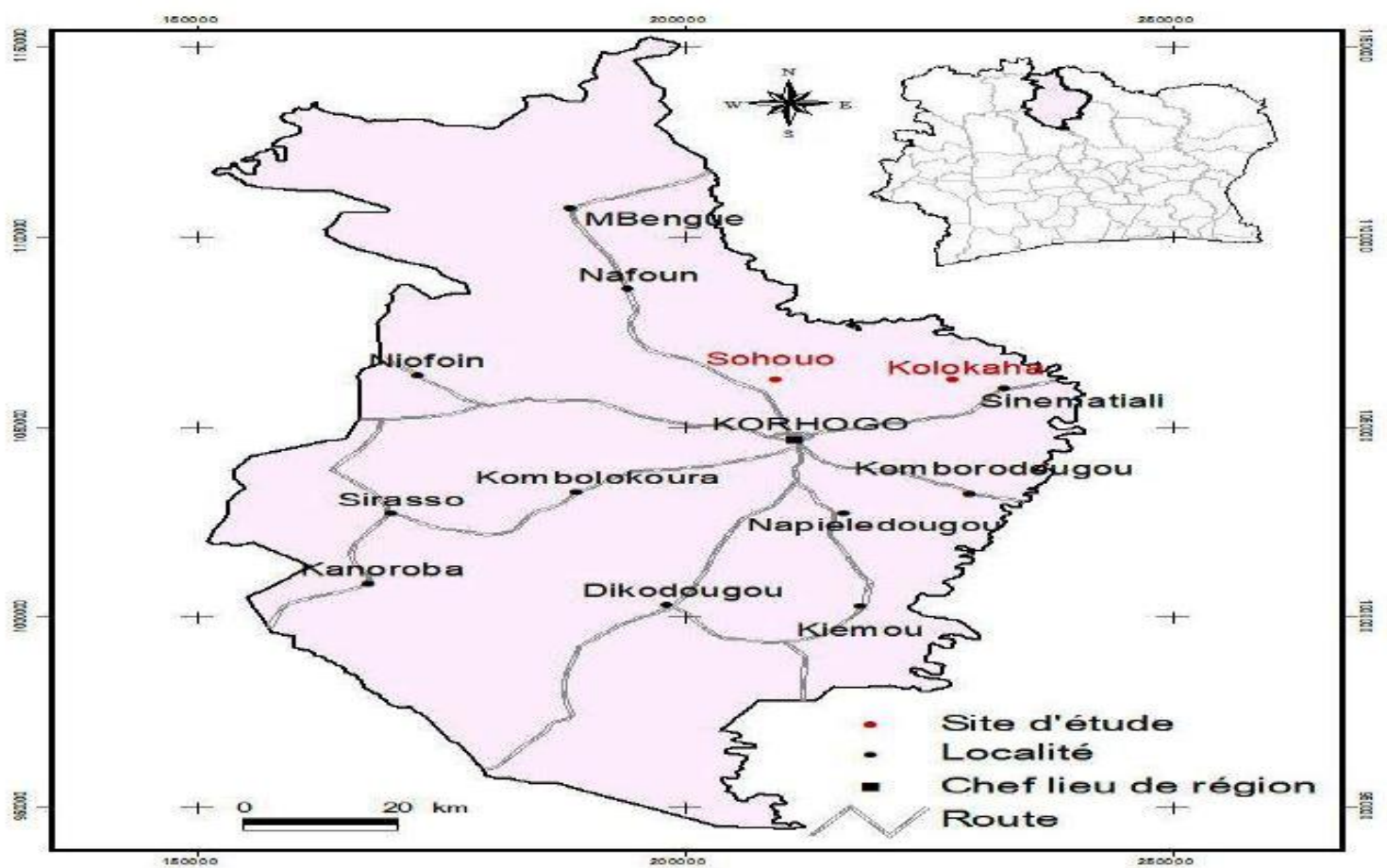

Fig.1: Map showing the location of the study areas. 


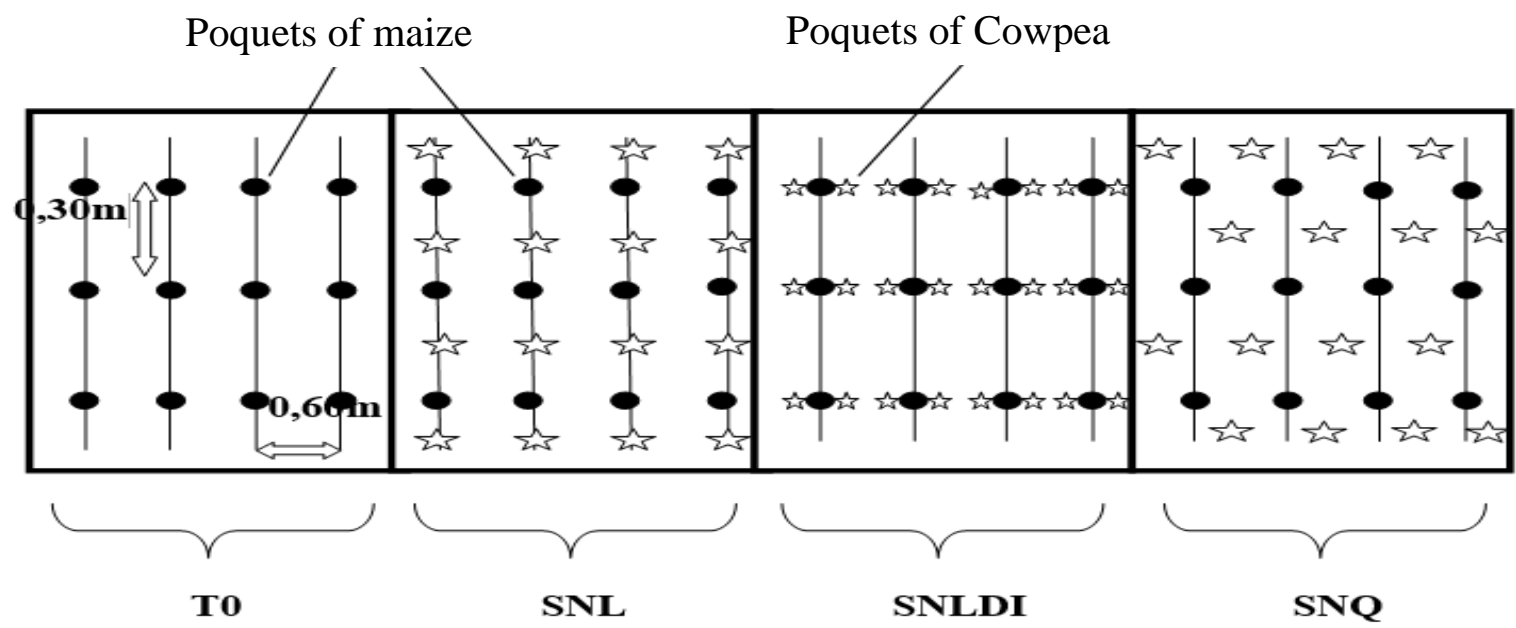

Fig.2: Maize and cowpea semi points in the association system

$>$ T0: maize seed in pure culture

$>$ T1-SNL: corn-semi-cowpea seed interposed

$>$ T2-SNLDI: semi-cowpea corn seed in double interbedded line

$>$ T3-SNQ: semi-stale corn seed staggered

There were 16 semi points when cowpea is sown in intercalated line (SNL) and quinconce (SNQ), or 16 cowpea plants per line for a density of 208 plants per elementary plot. In addition, when cowpea is sown in a double interspersed line (SNLDI), there were 32 plants on each line equivalent to a density of 416 plants $/ 30 \mathrm{~m}^{2}$. All of these plots benefited from fertilizer inputs and insecticide treatments. For analysis purposes, soil sampling was conducted using the method described by Ouattara et al. (2011). It was carried out at the scale of the plot, considered a space of homogeneous physiognomy and cultural history in order to assess the impact of corncowpea associations on the initial characteristics of the soil. Also, given that changes under crop systems are taking place more rapidly in the surface layer (Azontonde et al., 1998; Koutika et al., 2001; N'guessan et al., 2015), in this study, we considered the layers $(0-20 \mathrm{~cm})$ as levels of soil sample collection for laboratory chemical analyses. With this in mind, four treatments were considered in this study at each of the two study sites. These are pure-grown corn treatments (T0); corn - cash in intercalated line (SNL); double-line cowpea corn (SNLDI) and a natural fallow more than 30 years old. On each of these elementary plots, 04 composite soil samples were compiled by processing and demonstration plot and on the natural fallow of 16 samples per locality for a total of 32 samples at all two sites. The samples were taken using an auger at the end of the growing season in December 2018.

\subsection{Laboratory analysis}

They were carried out in the soil and plant laboratory of the Higher School of Agronomy (E.S.A), of the National
Polytechnic Institute Félix Houphouët-Boigny (INP-HB) of Yamoussoukro. The soil samples were first dried on newspaper at room temperature in laboratory B of Peleforo Gon Coulibaly University in Korhogo and then sieved with a $2 \mathrm{~mm}$ square mesh sieve. On these fine earth samples, the particle size analysis was carried out by the densimetric method using the Robinson pipette (Gee and Bauder, 1986). Five particle size classes have been separated: clays $(0-2 \mathrm{Nm})$; fine stringers $(2-20 \mathrm{Nm})$; coarse silt $(20-50 \mathrm{Nm})$; fine sands $(50-200 \mathrm{Nm})$; coarse sands (200-2000 Nm). The $\mathrm{pH}$ of the water was measured by electrometry, in a suspension of soil in water in a ratio of 1 / 2.5. The organic carbon (C) was measured according to the method of Walkley and Black (1934). As for total nitrogen, it was determined by the Kjeldahl method (Bremner, 1996). The exchangeable bases and the cation exchange capacity were measured in an ammonium acetate $(\mathrm{CH} 3 \mathrm{COOH} 1 \mathrm{~N})$ extraction solution buffered to $\mathrm{pH} 7$ (Thomas, 1982). The available phosphorus was determined by the modified Olsen Dabin method. As for total phosphorus, it was determined by colorimetry, after extraction with perchloric acid (Olsen and Sommers, 1982). With the analysis results, the structural stability index (St) and the beat index (IB) were calculated according to the formulas below. Pieri (1989) proposed the St index to characterize the structure of a soil. Indeed, the structure would be degraded for $\mathrm{St}<5$ and good for $\mathrm{St}>9$. It is determined according to the following formula :

$$
S t=(M O \% x 100) /(A+L) \%
$$


For the beat, the index was calculated according to the formula :

$$
\begin{aligned}
& \text { IB } \\
& =\frac{(1,5 \times \% \text { fine stringers })+(0,75 \times \text { coarse stringers })}{(\% \text { clay }+10 \times \% \text { organic matter }} \\
& -C \\
& \checkmark \quad \text { si } \mathrm{pH}<7, \mathrm{C}=0 \text {; } \\
& \checkmark \quad \text { si } \mathrm{pH}>7, \mathrm{C}=0,2(\mathrm{pH}-7)
\end{aligned}
$$

\subsection{Statistical analysis}

Comparison of soil character averages of different treatments began with variance analysis (ANOVA) at the $5 \%$ probability threshold. When a significant effect is noted between the different factors for a given parameter, the test of the smallest significant difference (ppds) was performed by the TUKEY method. All of these statistical tests were conducted using STATISTICA 7.1 software.

To better appreciate the evolution of soil parameters over time, the rate of evolution was calculated for each of them according to the following formula.

Evolution rate $(\%)=\frac{\text { final value-initial value }}{\text { initial value }} * 100$

final value : content of the element in the soil of any treatment

initial value : element content in the reference soil

\section{RESULTS}

\subsection{Granulometric characters of the soils studied}

Table I shows the average proportion of the granulometric fraction (clay, fine silt, coarse silt, fine sand and coarse sand) of the soils of each study site based on treatments and natural fallow. On all two study sites, the results reveal that natural fallow soils are significantly richer in clay (A$28.33 \%$ in Kolokaha; A - $47 \%$ in Sohouo) compared to the soils of the two demonstration plots (A-19.83\% in Kolokaha; A - 10.16\% in Sohouo) having undergone the practice of continuous cultivation for several years. This represents an initial loss of clay of $30 \%$ and $78.38 \%$ respectively of the soil of the Kolokaha and Sohouo demonstration plots. The introduction of the associated maize-cowpea crop system on plots also resulted in a 34.44 per cent and 63.04 per cent reduction in the clay content in the soils of the T1-SNL and T2-SNLDI treatments in the Kolokaha plot. On the other hand, there was a slight trend in Sohouo to increase the proportion of clay in the soil of the SNLDI treatment by 34.64 per cent compared to a 14.76 per cent decrease in the soil of the SN treatment. For fine and coarse silt, there is no significant difference in Kolokaha between natural fallow soils and those from demonstration plots. Nevertheless, there was a slight enrichment of the soil of the demonstration plot of
20.75 per cent fine silt and 29.56 per cent coarse silt. In Sohouo, there is a marked difference in the proportion of fine and coarse silt from the natural fallow soil compared to the soil of the demonstration plot. Natural fallow soil is significantly richer in fine and coarse silt compared to the soil of the demonstration plot. The difference is $45.31 \%$ and $41.58 \%$, respectively, of fine and coarse silt. In Kolokaha, the implementation of the maize-cowpea cultivation system had no effect, after 05 months of cultivation, on the proportion of fine and coarse silt of the soil of the elementary treatment plots (NLS). However, there is a downward trend of 9.63 per cent fine silt versus 5.63 per cent enrichment of coarse silt from the soil of these corresponding plots. In the elementary plots of SNLDI treatments, the proportion of fine and coarse silt is significantly lower than the corresponding values obtained at the Level of SNL treatments and the control plot without cowpeas. Thus, at the Kolokaha site, the decline in these elements was done with the semi density of the cowpea.In Sohouo, the basic plots SNL and SNLDI have a significantly higher proportion of fine silt than the cowpeafree control plot. With regard to fine sand and at the Kolokaha site, table I data show that prior to the installation of the crop, there is a similarity in its content in the soils of the demonstration plots ( 26.78 per cent). and under natural fallow (29.68\%). The same is true for coarse sand content, although there is a 28.46 per cent enrichment trend in this element in the soil surface layer of the demonstration plot compared to natural fallow soil. 
Table I : Granulometric characteristics of soils of plots grown on baseline soil

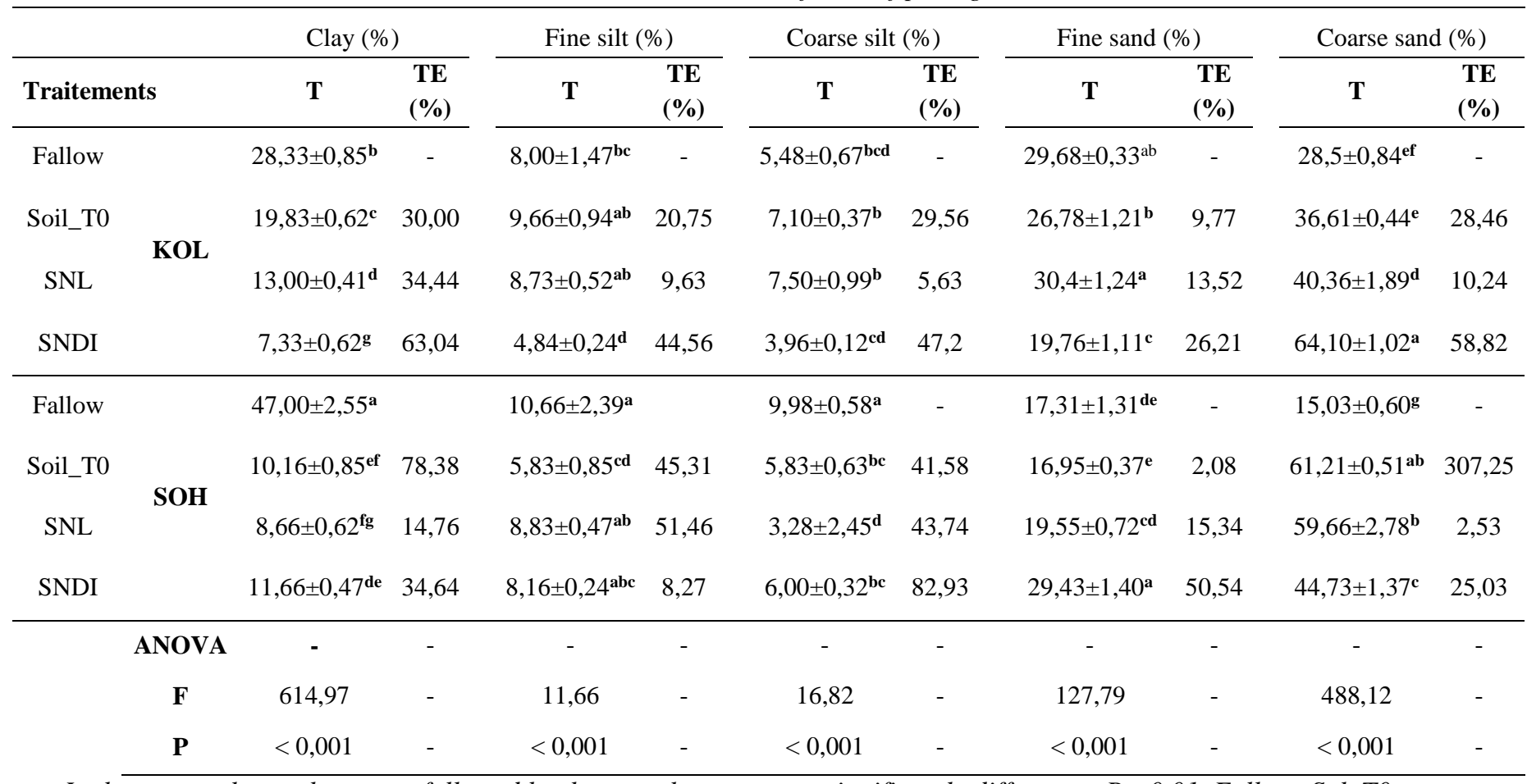

In the same column, the means followed by the same letter are not significantly different at $P<0.01$, Fallow: Sol_T0: pure culture without cowpeas; SNL: SNL: treatment of interspersed online cowpea; SNLDI: treatment_semi cowpea in double intercal line, Kol: Kolokaha; SOH: Sohouo, T: element content or value; TE: Evolution rate.

In Sohouo, there is no significant difference between the fine sand proportion of the natural fallow soil and that of the demonstration plot before the cultivation was installed. On the other hand, there is initially a significant difference between the coarse sand content of the natural fallow soil $(15.03 \%)$ demonstration plot $(61.21 \%)$. This represents a coarse sand enrichment of $307.25 \%$ of the soil of the demonstration plot compared to the soil under natural vegetation. Five (05) months after the experiments were set up and at the Kolokaha site, the fine sand proportion of SNL treatments appeared significantly higher than the cowpea-free control soil with an enrichment rate of $13.52 \%$. On the other hand, there was a $26.21 \%$ decrease in the proportion of fine sand (19.76 per cent) snite sNLDI plots with high cowpea semi density compared to the cowpea-free control soil. For coarse sand, its proportion increased with the presence and density of cowpea semi. Also, the values obtained at the level of SNL and SNLDI treatments are significantly higher than those obtained on the soil of control plots without cowpeas. Enrichment was $10.24 \%$ and $75.09 \%$, respectively, in the soils of the SNL and SNLDI elementary plots compared to the soil of the cowpea-free control plot.

In Sohouo, the proportion of fine sand is significantly higher in the soils of the SNL and SNLDI elementary plots compared to the control soil without cowpeas. As a result, there was an enrichment of $15.34 \%$ and $73.63 \%$ of fine sand respectively in the soils of the SNL and SNLDI elementary plots. In contrast, the proportion of coarse sand decreased with the semi density of cowpea. The decrease was $2.53 \%$ and $26.92 \%$, respectively, in the SNL and SNLDI elementary plots compared to the cowpea-free control plots.

Under current conditions of use, Table II data indicate that the soils of all treatments in each of the two demonstration plots, including those of natural fallows, are non-beating (IB -1.4). In terms of structural stability, the results also reveal that there is a significant difference between treatment soils and natural fallow. But the soils are very stable (Is 1) in the treatments of each of the two demonstration plots including those of natural fallows.

\subsection{Physical-chemical characteristics of the soils studied}

\subsubsection{Organic carbon and soil acidity}

Table III shows the $\mathrm{pH}$, and total organic carbon content, nitrogen and soil phosphorus of the two demonstration sites, initially under continuous cultivation for several years compared to the natural fallow soil. Prior to the establishment of crops at all two study sites, the results show that the total carbon content is significantly higher ( $\mathrm{p}$ -0.001 ) under natural fallow ( $\mathrm{T}-2.40 \%$ in Kolokaha; $\mathrm{T}$ $2.55 \%$ in Sohouo) compared to the soils of the 
demonstration plots ( $\mathrm{T}-1.28 \%$ in Kolokaha; $\mathrm{T}-0.93 \%$ in Sohouo). There was a 46.67 per cent and 62.37 per cent drop in total carbon soils in kolokaha and Sohouo cowpeafree demonstration plots compared to natural fallow soils. The same is true for nitrogen and phosphorus, which are higher in naturalfyding soils compared to soil levels in demonstration plots (Table III). At the end of the 2018 growing season, the combination of cowpea and maize in elementary plots had a significant effect on the carbon, nitrogen and soil acidity of the basic plots in pure cowpea cultivation. . In Sohouo, the carbon content increased in the surface layers of the soils of the elementary plots with the semi density of the cowpea. Indeed, carbon content $(1.51 \%)$ nitrogen $(0.09 \%)$ are significantly higher in elementary plots with high cowpea semi density (SNLDI) with maize compared to soil-level plots from pure cowpeafree elementary plots $(\mathrm{C}-0.93 \% ; \mathrm{N}-0.05$ per cent.

Table I: Changes in the Structural Instability Index and the Weight Index

\begin{tabular}{|c|c|c|c|c|c|}
\hline Traitments & & IB & TE $(\%)$ & ST & TE $(\%)$ \\
\hline Fallow & \multirow{4}{*}{ KOL } & $0,24 \pm 0,05^{\mathbf{c}}$ & - & $0,5 \pm 2,47^{\mathrm{cd}}$ & - \\
\hline SoIl_T0 & & $0,47 \pm 0,01^{\mathbf{b}}$ & 95,83 & $0,9 \pm 0,48^{a}$ & 80,0 \\
\hline SNL & & $0,51 \pm 0,04^{\mathrm{ab}}$ & 8,51 & $0,7 \pm 0,40^{\mathrm{bc}}$ & 22,2 \\
\hline SNDI & & $0,44 \pm 0,03^{\mathbf{b}}$ & 6,38 & $0,6 \pm 0,10^{\text {cd }}$ & 33,3 \\
\hline Fallow & \multirow{4}{*}{ SOH } & $0,26 \pm 0,05^{\mathbf{c}}$ & - & $0,8 \pm 0,24^{\mathrm{ab}}$ & - \\
\hline SoIl_T0 & & $0,50 \pm 0,06^{\mathbf{b c}}$ & 92,3 & $0,8 \pm 0,36^{\mathrm{ab}}$ & 0,0 \\
\hline SNL & & $0,6 \pm 0,09^{a}$ & 20 & $0,7 \pm 1,32^{\mathrm{bc}}$ & 12,5 \\
\hline \multirow[t]{4}{*}{ SNDI } & & $0,45 \pm 0,02^{\mathbf{b}}$ & 10 & $0,4 \pm 0,34^{\mathrm{d}}$ & 42,9 \\
\hline & ANOVA & - & - & - & - \\
\hline & $\mathbf{F}$ & 25,25 & - & 9,54 & - \\
\hline & $\mathbf{P}$ & $<0,001$ & - & $<0,001$ & - \\
\hline
\end{tabular}

In the same column, the means followed by the same letter are not significantly different at $P<0.01$, Fallow: Sol_T0: pure culture without cowpeas; SNL: SNL: treatment of interspersed online cowpea; SNLDI: treatment_semi cowpea in double intercal line, Kol: Kolokaha; SOH: Sohouo, T: element content or value; TE: Evolution rate.

This resulted in an increase of $63.53 \%$ and $68.75 \%$ respectively in the carbon and total nitrogen content in the soil layer of the SNLDI elemental plots. There are no significant differences in these parameters between soillevel values of low-density, semi-dented snare sunntos and pure-grown, cowpea-free plots. Nevertheless, there has been a $10.75 \%$ increase in total carbon in the soil layers of the sNL elementary plots compared to pure cowpea-free plots. In Kolokaha, there is no significant difference between the total carbon content of the soil layers of the elemental plots in associated cultivation compared to the soil values of pure cowpea-grown plots. However, there is a $7.81 \%$ increase in organic carbon in the soil layer of the low-density semi-SNL elemental plot. On the other hand, organic carbon falls by 27.34 per cent to the semi-density elementary plot (SNLDI) compared to the basic plot in pure cowpea-free cultivation. This trend of evolution of organic carbon content is identical to that of nitrogen. With regard to soil acidity and at each of the two study sites, there was no marked difference for this parameter between the soil layers of the elementary plots in associated cultivation of those of pure-grown, cowpea-free soils. In
Sohouo, the results indicate that the $\mathrm{pH}$ is relatively higher in the low elementary plots $(\mathrm{pH}-6.0)$ and high density (pH - 6.1) of semi cowpea compared to the soil of elementary plots in pure cowpea culture $(\mathrm{pH}-5.7)$. Thus, there has been a tendency to raise the $\mathrm{pH}$ of the soil with the semi density of the cowpea. The improvement in soil acidity was $4.51 \%$ and $6.93 \%$ respectively in the surface layers of the soils of the low-fat (SNL) and high-density (SNLDI) soil plots of cowpea-free crops. At the Kolokaha site, soil acidity improved by $4.18 \%$ and $3.64 \%$, respectively, in the SNL and SNLDI elementary plots compared to basic plots in pure cowpea-free cultivation. At the $\mathrm{C} / \mathrm{N}$ ratio, the values are less than 15 in the soil layers of all the plots studied at the Kolokaha site. The lowest value $(\mathrm{C} / \mathrm{N}-9.63)$ is recorded in the soil surface layer of the SNL elementary plot. 
Table III: Evolution of organic carbon, nitrogen, phosphorus and soil pH content of different agrosystems.

\begin{tabular}{|c|c|c|c|c|c|c|c|c|c|c|c|}
\hline \multirow[b]{2}{*}{ Traitments } & \multirow[b]{2}{*}{ Sites } & \multicolumn{2}{|c|}{ Organic carbon } & \multicolumn{2}{|c|}{ Nitrogen } & \multicolumn{2}{|c|}{$\mathrm{C} / \mathrm{N}$ ratio } & \multicolumn{2}{|l|}{ pHeau } & \multicolumn{2}{|c|}{ Phosphorus } \\
\hline & & $\mathbf{C}$ & $\begin{array}{c}\text { TE } \\
(\%)\end{array}$ & $\mathbf{N}$ & $\begin{array}{c}\text { TE } \\
(\%)\end{array}$ & $\mathbf{C} / \mathbf{N}$ & $\begin{array}{c}\text { TE } \\
(\%)\end{array}$ & pH & $\begin{array}{c}\text { TE } \\
(\%)\end{array}$ & Pass & $\begin{array}{c}\text { TE } \\
(\%)\end{array}$ \\
\hline Fallow & & $2,40 \pm 0,53^{\mathrm{a}}$ & - & $0,18 \pm 0,04^{\mathrm{a}}$ & - & $13,42 \pm 1,32^{\mathrm{cd}}$ & - & $5,90 \pm 0,65^{\mathrm{ab}}$ & - & $63,66 \pm 10,87^{\mathrm{a}}$ & - \\
\hline Soil_T0 & & $1,28 \pm 0,14^{\mathrm{ab}}$ & 46,67 & $0,10 \pm 0,01^{\mathrm{b}}$ & 44,44 & $13,3 \pm 1,03^{\mathrm{cd}}$ & 0,89 & $5,50 \pm 0,00^{\mathrm{bc}}$ & 6,78 & $41,33 \pm 0,47^{\mathrm{bc}}$ & 35,08 \\
\hline SNDI & & $0,93 \pm 0,02^{\mathrm{c}}$ & 27,34 & $0,08 \pm 0,00^{\mathrm{bc}}$ & 20 & $12,13 \pm 0,93^{\mathrm{d}}$ & 8,8 & $5,70 \pm 0,00^{\mathrm{abc}}$ & 3,64 & $45,66 \pm 3,09^{\mathrm{bc}}$ & 10,48 \\
\hline Fallow & & $2,55 \pm 0,10^{\mathrm{a}}$ & - & $0,16 \pm 0,00^{\mathrm{a}}$ & - & $15,65 \pm 0,91^{\mathrm{bc}}$ & - & $5,20 \pm 0,08^{c}$ & - & $49,33 \pm 0,47^{\mathrm{b}}$ & - \\
\hline Soil_T0 & & $0,93 \pm 0,07^{\mathrm{c}}$ & 63,53 & $0,05 \pm 0,01^{\mathrm{c}}$ & 68,75 & $18 \pm 2,32^{\mathrm{a}}$ & 15,02 & $5,77 \pm 0,05^{\mathrm{ab}}$ & 10,96 & $43,00 \pm 1,41^{\mathrm{bc}}$ & 12,83 \\
\hline SNL & SUH & $1,03 \pm 0,02^{\mathrm{bc}}$ & 10,75 & $0,05 \pm 0,00^{\mathrm{c}}$ & - & $19,51 \pm 2,05^{\mathrm{a}}$ & 8,39 & $6,03 \pm 0,05^{\mathrm{ab}}$ & 4,51 & $45,33 \pm 3,40^{\mathrm{bc}}$ & 5,42 \\
\hline SNDI & & $1,51 \pm 0,03^{\mathrm{b}}$ & 62,37 & $0,09 \pm 0,00^{\mathrm{bc}}$ & 80 & $17,41 \pm 0,60^{\mathrm{ab}}$ & 3,28 & $6,17 \pm 0,05^{\mathrm{a}}$ & 20,59 & $37,33 \pm 4,50^{\mathrm{c}}$ & 13,19 \\
\hline & ANOVA & - & - & - & - & - & - & & - & & - \\
\hline & $\mathbf{F}$ & 40,83 & - & 36,13 & - & 26,08 & - & 6,76 & - & 12,63 & - \\
\hline & $\mathbf{P}$ & $<0,001$ & - & $<0,001$ & - & $<0,001$ & - & $<0,001$ & - & $<0,001$ & - \\
\hline
\end{tabular}

In the same column, the averages followed by the same letter are not significantly different at P-0.01, Fallow: Sol_T0: pure cowpea-free cultivation; SNL: SNL: online_semi cowpea treatment; SNLDI: treatment_semi double intercale cowpea, Kol: Kolokaha; SOH: Sohouo, T: content or value in elements; TE: Rate of evolution.

On the other hand, on the Sohouo site, the $\mathrm{C} / \mathrm{N}$ ratio is greater than 15 and there is no significant difference in this parameter between the values obtained in the elementary plots in associated culture (C/N of SNL - 19.51; SNLDI $\mathrm{C} / \mathrm{N}$ - 17.41) compared to pure-grown plots ( $\mathrm{C} / \mathrm{N}$ - 18). As for phosphorus, its content remained almost invariable regardless of the study site and treatment. Nevertheless, there is a slight tendency in Kolokaha to enrich phosphorus with the semi density of cowpea. This slight increase in phosphorus was $0.8 \%$ and $10.48 \%$, respectively, in the SNL and SNLDI elementary plots compared to pure cowpea-free plots. In Sohouo, the trend towards phosphorus enrichment was $5.42 \%$ in the soil of the basic SNL plots. Table V data indicate a $13.19 \%$ downward trend in phosphorus content in the soil layers of elementary semi-density plots of cowpea semi (SNLDI) compared to the soil layers of pure-grown elementary plots.

\section{DISCUSSION}

The results of the study revealed a significant drop in the clay content and a decrease in the organic carbon stock in the soils of the demonstration plots before cultivation compared to soils under natural vegetation whatever the study site. These results are attributable to the practice of continuous cultivation of the land and the heavy use of pesticides and chemical fertilizers by farmers and confirm the work of N'guessan et al., (2019a and 2019b). They also corroborate the conclusions of N'guessan et al., (2015a), de Coulibaly et al., (2012) and Koulibaly et al., (2016) who made similar observations respectively in the north of Côte d'Ivoire. and in the cotton zone of Burkina Faso. In fact, in the agricultural landscape of the savannah district of the Ivory Coast, the mechanization of cotton and cereal farms intervenes in a privileged and systematic way for soil preparation. Because plowing is a particularly painful task to be carried out manually by producers. This is in line with the work of N'guessan et al., (2015a) who observed a compaction of cultivated soils in the departments of Ferkessédougou and Boundiali in the north of Côte d'Ivoire. According to the authors, the origin of the compaction of these soils is linked to their weak humiferous impregnation, to the increase in the apparent density with poor permeability and to the decrease in the hydraulic conductivity. Faced with this situation, the use of mechanization by harnessed or motorized cultivation has proven to be very effective in rural areas. In doing so, the clay content and the organic reserves of cultivated soils undergo numerous transformations over time under the constraint of changes in land use, the intensification of the use of resources and the vertical migrations of these elements. especially clay under the effect of infiltration water and their accumulation in depth. This result is in agreement with the work carried out in Tunisia by Annabi et al., (2009) which showed that the contents of total organic carbon (TOC) and total nitrogen (Ntotal) are 
closely related to the type of occupation of the ground. They observed that the forest soils of northern Tunisia contain $2.4 \%$ of TOC and $0.21 \%$ of Ntotal against 1.4 and $0.14 \%$ of TOC and Ntotal respectively for cultivated soils. This result also joins those of the works of Koulibaly et al., (2010) which obtained after 25 years of cultivation of the soil $44 \%$ reductions in carbon contents. Our results also agree with those of Tchienkoua (1999) who, in Cameroon, observed losses of $51 \%$ of total carbon, $43 \%$ of total nitrogen, $20 \%$ of phosphorus and $30 \%$ of fine sands after 3 years of setting in food crop cultivation. In Côte d'Ivoire, Ballo (2009) recorded, in the $0-20 \mathrm{~cm}$ layer, after twenty years of oil palm cultivation, losses of $70 \%$ of total carbon compared to the control soil under natural vegetation. Thus, the low richness of clay and organic elements in the soils of the demonstration plots reported by our results would thus be linked to their accelerated destruction during the execution of the plowing operations. It thus affects soil organisms directly by injuring, killing or exposing them to the risk of predation. This analysis agrees with those of annabi et al., (2009) who confirm that soil micro-organisms are the main driving force for destocking soil OM, since in the presence of favorable conditions (temperature, humidity, etc.), $\mathrm{OM}$ are the source of carbon and energy for these heterotrophic organisms. The tillage thus affects the biotic and abiotic factors of the soil, either directly by modifying the structural properties of the soil such as the arrangement of voids, aggregates, the connectivity of the pores, or indirectly by changing the aeration conditions, temperature and penetration of the soil by the roots. Our results revealed that the loss of clay and total carbon resulted in significant coarse sand enrichment of cultivated soils compared to reference soils. This has induced a particular structure to all cultivated soils in which, the solid constituents are piled up without any bond, for lack of colloids. Because of their size and the large spaces that separate them, these coarse sands make the soil filtering and light. According to Soltner (1992), reported by N'guessan et al., (2015b), when coarse sands dominate in a soil, they promote the penetration of water and air, retain little water and facilitate temperature exchanges. The soil heats up quickly in the dry season, and its constituents cannot clump together. This result corroborates the conclusions of Koné et al., (2008) and N'guessan et al., (2015b) who obtained similar results on soil quality in the humid savannah area of Côte d'Ivoire.

In the methods for combining cowpea corn, the results revealed a significant effect of cowpea on the organic carbon, nitrogen and soil acidity compared to the reference soil. In fact, in the associated crop plots, there was an increase in the organic carbon and total nitrogen content in the treatment of high semi-density of cowpeas compared to the values obtained at the level of the control plot without cowpea. The presence of cowpea also induced a significant increase in soil acidity in the treatments with low and high density of semi compared to the reference soil. It is likely that these qualitative changes in soil in the associated crop stimulate biological activity and modify a number of physical properties of the soil. These results are similar to those of Triomphe (1996), in North Honduras, who observed, in the long term, for a culture of corn associated with mucuna every year, an increase in the contents of $\mathrm{C}$ and $\mathrm{N}$ and exchangeable bases and absence of acidification. According to Latati et al., (2014) legumes can reduce nitrogen deficiency in the soil $(\mathrm{N})$ by the symbiotic fixation of nitrogen in the air and change the soil $\mathrm{pH}$.

\section{CONCLUSION}

At the end of this work, we can remember that the appropriate management of cultivated soils can allow carbon storage, in addition to the additional advantage of maintaining the resulting level of soil fertility. In Sohouo, the carbon $(1.51 \%)$ and nitrogen $(0.087 \%)$ contents increased by $62.36 \%$ and $74 \%$ respectively in the high density semi-cowpea treatments with corn compared to those obtained in reference ground level (C: 0.93\%; N: $0.05 \%$ ). Despite the increasing trend, no significant difference was noted for these parameters between the low-density semi-cowpea treatments associated with corn and the reference soil. As in Sohouo, there was an upward trend of $7.81 \%$ of organic carbon in the soil layer of the low density semi-SNL elementary plot. The presence of cowpea with maize raised the soil $\mathrm{pH}$ of the Kolokaha site by $4.18 \%$ and $3.64 \%$ respectively in the low and high density semi-cowpea treatments compared to the soil of elementary plots. in pure culture without cowpeas. The corn-cowpea association modalities thus constitute an alternative to the sustainable management of soil fertility in the north of Côte d'Ivoire.

\section{ACKNOWLEDGEMENTS}

The authors thank the Republic of Korea through the Korea Africa Food and Agriculture Cooperation Initiative (KAFACI) for approval of this program as part of the Young Scientist Pilot Research Project.

\section{REFERENCES}

[1] Annabi M, Bahri H., Latiri K. 2009. Statut organique et respiration microbienne des sols du nord de la Tunisie. Biotechnol. Agron. Soc. Environ., 13 (3): 401-408. 
[2] Avenard JM. 1971. Les sols dans le milieu naturel de la Côte d'Ivoire. M émoire ORSTOM, Paris. (50): 269-391.

[3] Ballo Koffi Célestin. 2009. Incidences de la fertilisation à base de potassium sur les composantes du rendement du palmier à huile (Elaeis guineensis jacq.) et sur les caractéristiques du sol : cas des ferrasols du sud de la Cote d'Ivoire. These de Doctorat, Université de Cocody, Abidjan, Cote d'Ivoire. 219 p.

[4] Bambara D., Zoundi J.S ., Tiendrébéogo J-P., 2008. Association céréale/légumineuse et intégration agricultureélevageen zone soudano-sahélienne. CahiersAgricultures, Vol. 17 (3) : 297-301.

[5] BARRO Awa, SANGARE Mamadou, COULIBALY Kalifa, KOUTOU Mahamoudou et DIALLO Mahamadoun A. 2016. Etude des modalités d'associationmaïs/niébé dans les villages de Koumbia etGombêlêdougou en zone cotonnière de l'Ouest du BurkinaFaso. Symposium International sur la Science et laTechnologie (SIST 2016). Sciences naturelles etagronomie. Spécial hors-série $\mathrm{n}^{\circ} 2$ : 151-163.

[6] Beaudou A. G.et Sayol. R. (1980). Etude pédologique de la région de boundiali-korhogo (Côte d'Ivoire). Edité par ORSTOM (Paris). $58 \mathrm{p}$

[7] COULIBALY Kalifa, GOMgnimbou Alain Péoulé Kouhouyiwo, TRAORE Mamadou, NACRO Hassan Bismarck et SEDOGO Michel Papaoba. 2017. Effetsdes associations maïs-légumineuses sur le rendement dumaïs (Zea mays L.) et la fertilité d'un sol ferrugineuxtrop ical à l'Ouest du Burkina Faso. Afrique SCIENCE13(6) : $226-$ 235.

[8] Coulibaly K., Vall, E. Autfray P. et Sedogo P.M. 2012. Performance technico-économique des associationsmaïs/niébé et maïs/mucuna en situation réelle de culture au Burkina Faso: potentiels et contraintes. TROPICULTURA. 30 (3) : 147-154.

[9] Gbakatchetche H., Sanogo S., Camara M., Bouet A., Keli J.Z., 2010. Effet du paillage par des résidus de poisd'angole (Cajanus cajan L.) sur le rendement du riz paddy (Oryza sativa) p luvial en zone forestière de Côte d'Ivoire. Agronomie Africaine, Vol. 22 (2) : 131-137.

[10] KOUASSI N'dri Jacob, KOFFI Ahébé Marie Hélène, YAH N'Guettia Marie, KOUAKOU Yao Isidor Junior et YATTY Kouadio Justin. 2017. Influence de la densitéde semis sur les paramètres agronomiques de trois variétésde niébé (Vigna unguiculata (L.) Walp, Fabaceae)cultivées en Côte d'Ivoire. Afrique SCIENCE 13(4) : 327-336.

[11] Koulibaly Bazoumana, Dakuo Déhou, Traoré Mamadou, Traoré Ouola, Nacro Hassan B., Lompo François, Sedogo Michel P. 2016. Effets de la fertilisation potassique des sols ferrugineux tropicaux sur la nutrition minérale et la productivité du cotonnier (Gossypium hirsutum L.) au Burkina Faso. International Journal Biological Chemical Sciences. 10 (2): 722-736.

[12] Koulibaly B, Traoré O, Dakuo D, Zombré PN, Bondé D. 2010. Effets de la gestion des résidus de récolte sur les rendements et les bilans culturaux d'une rotation cotonnier maïs-sorgho au Burkina Faso. Tropicultura, 28 (3): 184189.

[13] M. Latati, D. Blavet, N. Alkama, H. Laoufi, J.J. Drevon, F. Gérard, M. Pansu, S.M. Ounane. 2014. The intercropping cowpea-maize improves soil phosphorus availability and maize yields in an alkaline soil. Plant Soil (385):181-191.

[14] N'Goran Kouadio Emmanuel, Kassin Koffi Emmanuel, Kouakou Brou Julien, Gustave Francis Messoum, Brou Kouamé, Brou N'guessan Dominique. 2018. Diagnostic de l'état de fertilité des sols sous culturecotonnière dans les principaux bassins de production deCôte d'Ivoire. European Scientific Journal, 14 (33) : 221-238.

[15] N'GUESSAN Kouamé Antoine, ALUI Konan Alphone, DIARRASSOUBA Nafan et GNAGNE Agnes Vianney Landry Gasso. (2019b). Impact de la culture continue et l'intensification agricoles sur la teneur en carbone organique et la composition solide minérale des sols au nord de la Côte d'Ivoire. Journal of Applied Biosciences (142) : 14519 - 14528.

[16] N'GUES S AN Kouamé Antoine, KOUAKOU Konan Elie, ALUI Konan Alphoneet YAO - KOUAME Albert. 2019a. Stratégies et pratiques paysannes de gestiondurable de la fertilité des sols dans le département deKorhogo au Nord de la Côte d'Ivoire. Afrique SCIENCE15(4) : $245-$ 258.

[17] N'guessan Kouamé Antoine, Diarrassouba Nafan, ALUI Konan Alphonse, Nangha Krobga Yves, Fofana Insa Jésus, Albert Yao-Kouamé. 2015a. Indicateurs de dégradation physique des sols dans le Nord de la Côte d'Ivoire : cas de Boundiali et Ferkessédougou. Afrique SCIENCE 11(3) : 115 - 128.

[18] N'guessan Kouamé Antoine, Diarrassouba Nafan, Koné Brahima, ALUI Konan Alphonse, YAO Kouamé Albert. 2015b. Caractérisation morpho-pédologique et contraintes au développement de Lippia multiflora sur deux sols tropicaux de Côte d'Ivoire. Journal of Animal \& Plant Sciences. (24) 3: 3814-3828.

[19] OUATTARA Bassiriki, SANGARE Mamadou et COULIBALY Kalifa. 2016. Options pour uneintensification durable de la production agricole etfourragère dans le système de production agropastoral deszones cotonnières du Burkina Faso. SymposiumInternational sur la Science et la Technologie (SIST2016). Sciences naturelles et agronomie. Spécial horssérien $^{\circ} 2: 133-149$.

[20] Soltner Dominique. 1992. Phytotechnie générale : les bases de la production végétale. 19e édition. Collection Sciences et Techniques Agricoles. Tome I : le sol. 467p.

[21] Tchienkoua M. 1999. Evaluation de l'impact de l'érosion et de la mise en culture sur les concentrations en carbone, azote et phosphore labile sur sol ferralitique rouge $\mathrm{du}$ centre du Cameroun. In compte rendu du colloque international «l'homme et l'érosion》bulletin réseau érosion 19 : l'influence de l'homme sur l'érosion, p.158. Doc. IRD/CTA, 608 p. 
[22] Triomphe B., 1996 - Un système de culture original et performant dans une zone de montagne du tropique humide : la rotation maïs/mucuna au Nord-Honduras. Actes Séminaires du 13 au 17- 11 - 1995, Montpellier. CIRAD, Ministère de la Coopération : 3 18-328, Montpellier.

[23] Zoundi J.S ., Butare I. et Adomefa J.N.K., 2006. Intégration agriculture-élevage : Alternative pour une gestion durable des ressources naturelles et une amélioration de l'économie familiale en Afrique de l'Ouest et du Centre. Ouagadougou, INERA, Nairobi : ILRI, Dakar : CORAF/WECARD, $374 \mathrm{p}$. 